\title{
SYSTEMIC CHANGES THAT COULD REDUCE THE CONVICTION OF THE INNOCENT
}

\section{Arnold H. Loewy ${ }^{1}$}

In a utopian world, juries would always reach the correct result. In the real world, they don't. When they don't, which way do they tend to err? Which way do we want them to err? The theoretical answer to the second question is clear. We want juries to err on the side of acquitting guilty people rather than convicting innocent ones.

In the leading American case on requiring proof beyond a reasonable doubt, In Re Winship, ${ }^{2}$ the United States Supreme Court held that the Due Process Clause required a state to prove its case beyond a reasonable doubt in order to obtain a conviction. ${ }^{3}$ The Court identified three independent reasons for requiring this standard: (1) Fairness to the accused, (2) The community's need to be sure of the guilt of those it condemns, and (3) The security of every citizen in knowing that if he ever is accused of a crime, the State will have to prove its case against him beyond a reasonable doubt.

${ }^{1}$ George Killam Professor of Criminal Law-Texas Tech School of Law, Graham Kenan Professor of Law Emeritus-University of North Carolina School of Law. The author would like to thank Professor Richard A. Rosen of UNC Law School for educating me to many of these problems, and William Cross, a second year UNC Law Student, for his helpful research.

2397 U.S. 358 (1970).

${ }^{3}$ That was the universal practice in the U.S. at the time of the case anyway. The case arose in the oblique context of a juvenile proceeding where the State of New York argued that it was better for a 12 year old who probably stole money to be sentenced as a juvenile than to let him go in case he didn't do it. The Supreme Court rejected this reasoning even as applied to juveniles. 
Justice Harlan concurred on the ground that it is far worse to convict an innocent man than it is to acquit one who is guilty. But do we really believe that? How many guilty child molesters are we really willing to acquit to ensure that we don't convict one wrongly accused? Is it 10-, 100-1, or are we so afraid of criminals that if we think he's probably guilty, he's going to be convicted?

\section{A. The Prosecution's Advantage}

Most people think that a criminal trial favors the defendant. He is presumed innocent. The prosecutor must prove its case beyond a reasonable doubt. And the prosecution has all sorts of rules limiting its ability to conduct searches and seizures or obtain confessions. These apparent advantages, however, turn out upon reflection to be illusory. For the reasons given in the introduction to this paper, juries may not take the burden of proof seriously. The presumption of innocence is little more than a form of words indicating that the prosecution has the burden of proof (which the jury may not take seriously). Does anybody really believe that the average jury literally presumes that the defendant, who has been brought to trial by all the power the State can muster, is really innocent? I don't think so.

Furthermore, even the apparent constitutional limitations on search and seizure and confessions are in fact an advantage for the prosecution. The prosecutor might be limited by fairly conducted searches and fairly-obtained confessions, but at least she can seek them; the defendant cannot. Instead, if the defense wants evidence, it has to scratch and claw without the aid of a search warrant. If the defendant believes that somebody else committed the crime, he is not free to arrest or even question that person (unless, of course that person consents). Furthermore, the prosecution, with its professional police force and access to forensic laboratories, is far better able to obtain evidence (at least in the run-of-the-mill case) than is the defendant. $^{4}$

${ }^{4}$ See Laura Gardner Webster, Resources and Rights: Towards a New Prototype of Criminal Representation 44 MERCER L. REV. 599, 603-604 (1993

). 
I am aware of no reliable studies as to whether juries in fact wrongfully convict more than they wrongfully acquit. Indeed, I am not sure how we could ever know. Although there have been a few high profile cases where, at least some think, the defendant was wrongly acquitted, ${ }^{5}$ there is much evidence of an extraordinarily high number of wrongful convictions of innocent people that has recently been documented. ${ }^{6}$ Considering the number of these cases, I am inclined to believe that we convict at least as many innocent people as we acquit guilty ones. ${ }^{7}$

One possible fix is to redefine reasonable doubt. Perhaps if judges emphasized the concept more, juries would be more likely to give the defendants the benefit of it. Frankly, I don't think this will work. Good defense attorneys already emphasize (or should emphasize) the concept and not all wrongful convictions are the result of incompetent counsel (anymore than wrongful acquittals are the result of an incompetent prosecutor). The concept of reasonable doubt as "a doubt based on reason and common sense arising from the evidence or lack of evidence as the case might be," is probably as good as we could do. I don't think that we want to acquit people on the basis of a vain, imaginary, or fanciful doubt.

On the other hand, it might help if judges instructed juries that: "If you think that the defendant is probably guilty, or even if you are fairly certain that he is guilty, you should still return a verdict of not guilty unless you are convinced of this guilt beyond a reasonable doubt. This is important because everyone of us needs to know that if we are accused of a crime, we cannot be convicted unless the state proves us guilty beyond a reasonable doubt."

\section{B. Why Wrongful Convictions?}

${ }^{5}$ See e.g. O.J. Simpson, John Hinckley

6 The most serious academic study of exonerations in the United States identifies 340 total exonerations in this country between 1989 and 2003 (discounting several mass exonerations), including 144 individuals cleared by DNA. See Samuel R. Gross et al., Exonerations in the United States, 1989 through 2003, 95 J. CRIM. L. \& CRIMINOLOGY 523, 523-524 (2005). By 2005 the most prominent group devoted to investigating claims of innocence in the United States, The Innocence Project, has "freed more than 150 innocent people from prison" See Andrew M. Siegel, Moving Down the Wedge of Injustice: A Proposal For A Third Generation of Wrongful Conviction Scholarship And Advocacy, 42 AM. CRIM. L. REV. 1219 (2005) (Citing numbers from The Innocence Project's web page available at http://www.innocenceproject.org). See also J. Brent Alldredge, Federal Habeus Corpus and Post Conviction Claims of Actual Innocence Based on DNA Testing, 56 SMU L. REV. 1005 fn. 4 (2003) ("It is also significant to note that '[i]n more than a dozen cases, post-conviction DNA testing that has exonerated an innocent person has also enhanced public safety by providing evidence that led to the identification of the actual perpetrator.") (Citation omitted).

${ }^{7}$ If not, we make a lot of mistakes on both sides. 


\section{Misidentification}

An unusually large number of wrongful convictions are attributable to misidentification. ${ }^{8}$ The victim says confidently: "I can never forget those eyes. I saw them every second that he was raping me." Unfortunately, a disturbingly high number of eyes, later proved innocent by DNA evidence, have been wrongly identified in such a matter. ${ }^{9}$ The problem is simple. Eye witnesses think they are sure. Juries find this credible, and the wrong person is convicted.

This is not completely fixable. Eye witness identification has to be admissible. We can, however, take steps to make misidentification less likely. Of course, once she picks the one that looks most like the rapist, she is likely to fixate on those characteristics and remember them as belonging to her attacker. One thing that recent experiments think help is to run a series of showups or single picture identifications. That way the witness does not think that she has to pick one. ${ }^{10}$

${ }^{8}$ Gross, supra n. 6 at 542 ("The most common cause of wrongful convictions is eyewitness misidentification. This is not news. It was first shown in 1932 by Professor Edwin Borchard in his classic book Convicting the Innocent, and it is apparent again in our data: In 64\% of these exonerations (219/340), at least one eyewitness misidentified the defendant."). See also Margery Malkin Koosed, The Proposed Innocence Protection Act Won't, Unless It Also Curbs Mistaken Eyewitness Identification, 63 OнIо ST. L.J. 263 (2002).

${ }^{9}$ See e.g. Gross, supra n.6 at fn 56 (discussing the case of Ronald Cotton who was convicted of raping a woman named Jennifer Thompson. Thompson had spent an extended period with her attacker and had observed him closely so that she could identify him later on. When DNA evidence proved that Cotton was innocent Thompson went to great lengths to make amends to Cotton and to bring attention to his case.) See also Gregory v. Kentucky, No. 93-SC-878-MR (Ky. Nov. 23, 1993), discussed at length in Jessica Lee, No Exigency, No Consent: Protecting Innocent Suspects From The Consequences Of Non-Exigent Show-Ups, 36 Colum. HuM. RTS. L. Rev. 755, 790 (2005).

${ }^{10}$ See Suzannah B. Gambell, The Need to Revisit the Neil v. Biggers Factors: Suppressing Unreliable Eyewitness Identification, 6 WYO. L. REv. 189, 194-5 (2006) ("it has been shown that sequential lineups, where individuals are seen one at a time, subjects the witness to an 'absolute judgment.' In this type of lineup, a witness only views another person or photograph after they have decided whether the individual currently viewed is the perpetrator. This forces the witness to compare the individual with the witness's memory of the perpetrator, not with other individuals in the lineup. Research has shown that sequential lineups are more accurate and law enforcement are beginning to change procedures in this direction."); Barry Scheck, Cooley Innocence Project Kick Off, 18 T.M. CoOLEY L. REV. 167, 174 (2001)("You have seen it, five or six people standing in a row or a photo array - pictures one next to each other. Well, when you do that, there is a problem and the problem is, you have six people standing right in front of the witness. And you say, 'Do you see the person?' What you are doing is inviting a 
Another suggestion is to have the lineup conducted by someone who does not know who the suspect is. That way there is no risk of the lineup conductor, intentionally or unintentionally, giving the witness clues as to who she is supposed to pick. ${ }^{11}$ Neither of these proposals will eliminate misidentification. The best we can hope to do is reduce it. Perhaps defense attorneys can introduce statistics of misidentification to try to impeach the witness, but some misidentification resulting in wrongful conviction will still be with us.

\section{False Confessions}

relative judgment. Which of these six people most resembles the perpetrator. And the way human memory works is if you invite a relative judgment, you're going to get one.").

${ }^{11}$ See Jake Sussman, Suspect Choices: Lineup Procedures And The Abdication Of Judicial And Prosecutorial Responsibility For Improving The Criminal Justice System, 27 N.Y.U. Rev. L. \& Soc. ChANGE 507, 518 (2002) ("It is well documented that an investigator's unintentional cues, such as body language or tone of voice, may negatively impact the reliability of eyewitness evidence. Studies have shown that the margin of error for both sequential and simultaneous lineups is reduced when the test is done by an officer who is not involved in the investigation and does not know the identity of the suspect. Researchers have suggested that an investigator who knows which lineup member is the suspect can inadvertently or advertently bias the eyewitness through nonverbal behavior such as smiling and nodding."). 
Confessions are exceptionally damning. Few jurors believe that an innocent man or woman will falsely implicate him or herself. Unfortunately this is not true. Skillful questioners can and sometimes do actually convince a suspect, especially one who is young, not too bright, or easily led, that he did commit the crime. ${ }^{12}$ The best way to minimize this harm is to require police to videotape their confessions. That way if there is evidence of pressure on the defendant, the defense attorney, and possibly the jury will see it. This won't eliminate false confessions leading to convictions, but it will mitigate the damage.

\section{Bad Forensics}

${ }^{12}$ See Andrew E. Taslitz, Convicting the Guilty, Acquitting the Innocent, The ABA Takes A Stand, 19-WTR CRIM. JUST. 18, 23 (2005) ("The academic literature is replete with instances in which innocent persons have confessed to crimes that they did not commit. . . with some estimates attributing close to one-fourth of all convictions of the innocent partly to false confessions."). See also Steven A. Drizin and Richard A. Leo, The Problem of False Confessions in the Post-DNA World, 82 N.C. L. REV. 891, 963-974 (2004) (discussing highly vulnerable groups such as juveniles and the mentally ill and retarded and presenting several illuminating case studies where such people have wrongly confessed.). 
Bad forensics comes in any number of forms. A fingerprint expert may declare a match when there aren't enough points to truly compare. ${ }^{13}$ Or, the expert may inadvertently (or regrettably) even intentionally use the wrong print. Similarly DNA can be mishandled, or samples can be improperly analyzed or wrong samples can be taken. ${ }^{14}$ Of course any forensic evidence (serology, fibre samples etc) is only as good as the scientist performing the tests. And, despite judicial efforts to reign in junk science, ${ }^{15}$ neither junk science nor junk scientists are likely to disappear anytime soon.

The forensics problem really has two sides: deliberate and inadvertent error. It is my fondest hope that deliberate error is rare. When it is discovered, of course, disciplinary action should be swift and sure. ${ }^{16}$ Short of out-and-out dishonesty, experts may shade the truth (e.g. claim a fingerprint match out of a partial identification, where the expert believes that the defendant is guilty), which can lead to wrongful convictions.

When the bad forensics are inadvertent, we have to depend on defense counsel to counter with his or her own forensic expert. Unfortunately, this is easier said than done. Defense counsel are frequently underfunded, and forensics experts are not cheap. ${ }^{17}$ Unfortunately, the cost of not

${ }^{13}$ For a discussion of how fingerprint analysis works see Katherine Schwinghammer, Fingerprint Identification: How the "Gold Standard for Evidence" Could Be Worth Its Weight, 32 AM. J. CRIM. L. 265, 267 (2005). For another discussion of the process, concluding that more often than not it does not work, see Robert Epstein, Fingerprints Meet Daubert: The Myth of Fingerprint Science is Reveled, 75 S. CAL. L. REV. 605, 607 (2002).

${ }^{14}$ See J. Herbie DiFonzo, The Crimes of Crime Labs, 34 HofSTRA L. REV. 1, 2 (2005) ("DNA's reputation for scientific precision is in fact unwarranted. The record is littered with slapdash forensic analyses often performed by untrained, underpaid, overworked forensic technicians operating in crime labs whose workings reflect gross incompetence or rampant corruption..”). See also J. Herbie DiFonzio, In Praise of Statutes of Limitations in Sex Offense Cases, 41 Hous. L. REV. 1205, 1242-54 (2004) (describing the erroneous rape conviction of Josiah Sutton based on sloppy use of scientific evidence including DNA.).

${ }^{15}$ See e.g. Daubert v. Merrill Dow Pharmacy, 509 U.S. 579 (1993).

${ }^{16}$ See Craig M. Cooley, Reforming the Forensic Science Community To Avert the Ultimate Injustice, 15 STAN. L. \& POL'Y REV. 381, 399-408 (2004) (discussing the cases of experts such as Ralph Erdmann, who was convicted of faking autopsies that led to over twenty capital convictions, David Harding, who faked fingerprint evidence for the New York State police, and Pamela Fish, whose misconduct working for the FBI has led to at least seven wrongful convictions). For an interesting proposed solution see Carol Henderson Garcia, Expert Witness Malpractice: A Solution to the Problem of the Negligent Expert Witness, 12 Miss. C. L. REV. 39 (1991).

${ }^{17}$ See Stephen D. Easton, Ammunition For the Shootout With the Hired Gun's Hired 
doing this may be the conviction of still more innocent people.

\section{Jailhouse Confessions}

Gun: A Proposal For Full Expert Witness Disclosure, 32 ARIZ. ST. L.J. 465, 579 FN. 373 (citing a 1995 study that indicated that the average fee was $\$ 258$ per hour and that top expert witnesses can demand more than $\$ 1,000$ an hour). 
Although a confession made by a defendant to a cellmate while awaiting trial may, on occasions, be highly probative, the likelihood of such a confession contributing to an erroneous conviction is extraordinary high. ${ }^{18}$ A prisoner has little to lose by cooperating and can be given great incentives to testify in accordance with the prosecutor's wishes. Time off of his sentence or a reduction in charges are not uncommon prosecutorial ploys to coax such testimony from cellmates. ${ }^{19}$

Although I have at times been tempted to urge the inadmissibility of such evidence, I've ultimately rejected that position as too harsh. Sometimes a criminal defendant really does confess to a crime and gives sufficient detail that one can be confident that it is truthful. ${ }^{20}$ When this confession is made in jail or prison, it would go too far to preclude its admissibility. Juries should, however, be given a cautionary instruction something like this:

"Ladies and gentlemen of the jury. Bill Jones has testified that Joe Smith told him that he murdered his wife Mary with a hatchet that he hid near a tree by the lake where her body was discovered. The government has offered to drop three of the five burglary charges against $\mathrm{Mr}$. Jones in exchange for this testimony. You should carefully consider that in assessing whether or

${ }^{18}$ See Evan Haglund, Impeaching The Underworld Informant, 63 S. CAL. L. REV. 1405, 1416 (1990) (discussing the case of Leslie White, a jailhouse informant who admitted to perjuring himself in multiple cases as part of an ongoing relationship with the Los Angeles District Attorney's office. White reported that, using only a telephone, "he could gather enough information to convincingly fabricate the confession of a murder defendant whom he had never even met"); See also C. Blaine Elliott, Life's Uncertainties: How To Deal With Cooperating Witnesses and Jailhouse Snitches, 16 CAP. DEF. J. 1, 11-13 (2003) (Discussing numbers generated by The Innocence Project, discussed supra at n. 6, and Canada's nationally funded Morin Commission, which studies the issue in Canada, Australia, Great Britain, and America, suggesting that "Solid evidence exists that shows the dangers of cooperative witnesses and jailhouse snitches.").

${ }^{19}$ See Valerie Alter, Jailhouse Informants: A Lesson in E-Snitching, 10 J. TECH. L. \& POL'Y 223, 226 (2005) ("There is good reason for informants to fabricate testimony: they often get a break from prosecutors in the form of sentence reductions. They also lie for simple comforts. . that otherwise would be out of reach in jail."). This statement is dramatically illustrated by cases such as United States v. Boyd, 833 F. Supp. 1277 (N.D. Ill. 1993) where jailhouse informers who were members of a gang were nevertheless permitted "simple comforts" including contact visits, sex, illegal drugs, gifts, clothing, and telephone privileges. $I d$. at 1322-33. See also Elizabeth A. Ganong, Involuntary Confessions and the Jailhouse Informant: An Examination of Arizona v. Fulminante, 19 HASTINGS CONST. L.Q. 911, 930-31 (1992) (Discussing Fulminante, where Anthony Sarivola, like many jailhouse informants, was paid based on how much information he provide and how damning that information was.).

${ }^{20}$ See e.g. Perkins v. Illinois, 496 U.S. 292 (1991). 
not to believe Mr. Jones."

Although such a cautionary instruction will not prevent all wrongful convictions, it will move us in that direction.

\section{Living With Wrongful Convictions}

Because we know that wrongful convictions happen, we need to consider what impact that should have on some of our procedures. I offer four suggestions: (1). Innocence commissions, (2) Rules ensuring that relevant exculpatory evidence is not excluded, (3) Rejection of Capital Punishment. And (4) Elimination of repentance as a condition of parole.

\section{Innocence Commissions}

Innocence commissions work outside the usual confines of the criminal law. England has successfully employed one for years. ${ }^{21}$ One of the benefits of this is that by running parallel to the criminal law, it can detect actual innocence without disturbing finality. Courts typically do not like to disturb finality by hearing actual innocence claims. ${ }^{22}$ Innocence commissions can hear such cases, putting a heavy burden on the defendant, thus allowing the criminal justice system to keep its finality while at the same time giving a wrongfully convicted defendant the opportunity, albeit with a heavy burden, to prove his innocence.

\section{Allow All Relevant Exculpatory Evidence}

${ }^{21}$ After a number of high profile wrongful convictions in the late 1980s England began a formal study of the issue and in 1995 the Criminal Cases Review Commission was created to address the problem. For an in-depth discussion of the English system comparing and contrasting it with the existing American systems see Lissa Griffin, The Correction of Wrongful Convictions: A Comparative Perspective, 16 AM. U. INT'L L. REV. 1241 (2001)

${ }^{22}$ See e.g. Herrara v. Collins, 506 US 390, 411-16 (1993). 
Various evidence rules at one time or another have for one reason or another denied the defendant the opportunity to present relevant exculpatory evidence. At one time in the United States, various state rules forbade defendants from calling an alleged co-conspirator as a witness, ${ }^{23}$ impeaching one who denies previously confessing to a crime of which the defendant stands accused, ${ }^{24}$ and denying the defendant the benefit of hypnotically refreshed testimony. ${ }^{25}$ The United States Supreme Court has invalidated all of these practices. To be sure, not all conceivably relevant evidence favoring the defendant should necessarily be allowed to be introduced. For example, the United States Supreme Court was probably correct in ruling that evidence that the defendant passed a lie detector test could be excluded because of the inherent unreliability of such tests. ${ }^{26}$

A very recent Supreme Court case, Holmes $v$. South Carolina ${ }^{27}$ involved a young black defendant accused of rape and murder of an elderly white woman. The State's case was that witnesses had seen the defendant in the vicinity of the crime at the time of its commission and that forensics strongly implicated him. Holmes' defenses were that the forensic evidence was faulty and probably intentionally so, and that another young black man actually committed the crime.

Holmes was allowed to present evidence going to the faulty forensics, but he was not allowed to present evidence that somebody else committed the crime. In the South Carolina Court's view such evidence was only relevant to cast suspicion on another, and did not tend to prove Holmes' innocence. Fortunately the United States Supreme Court unanimously reversed this decision. In reversing, the Supreme Court described South Carolina's logic as follows: "Where (1) it is clear that only one person was involved in the commission of a particular crime and (2) there is strong evidence that the defendant was the perpetrator, it follows that evidence of third party guilt must be weak." 28

The Court rebutted that argument, noting that: "Just because the prosecution's evidence, if credited, would provide strong evidence for a guilty verdict, it does not follow that evidence of

${ }^{23}$ Washington v. Texas, 388 U.S. 14, 19 (1967).

${ }^{24}$ Chambers v. Mississippi, 410 U.S. 284 (1973).

${ }^{25}$ Rock v. Arkansas, 483 U.S. 44 (1987).

${ }^{26}$ See United States v. Scheffer, 523 U.S. 303 (1998).

27 --- S.Ct. ----, 2006 WL 1131853. (Draft prepared before availability of Supreme Court cite.)

${ }^{28} I d$. at 7 . 
third-party guilt has only a weak logical connection to the central issues in case." ${ }^{29}$ Concluding, that the court could not arbitrarily assume that the State's theory of the case was correct and that the defendant's counter-theory was faulty, the Court remanded the case, presumably for a new trial.

The importance of this case cannot be overemphasized. If the South Carolina rule were allowed to stand, the case could choose to prosecute A rather than B for a crime. At the trial, A would be precluded form introducing all of the evidence tending to implicate B. Thus the State's choice of defendants would have been given a free pass. State chose to attack A. A cannot attack B. Thus A is convicted and the jury never learns about B. The Supreme Court's rule prevents that and thus decreases the likelihood of an innocent person being convicted.

\section{Eliminate the Death Penalty}

${ }^{29} I d$. (emphasis in original) 
Although most civilized nations have eliminated the death penalty, the United States is not one of them. Capital punishment has been defended as a necessary restraint, necessary deterrence, and/or appropriate retribution. Without in any way endorsing these propositions, it seems clear that the calculus is drastically altered when we know that we convict innocent people. Given that we know that, and further know that it is highly unlikely that we can altogether eliminate ${ }^{30}$ this bleak reality, it is necessary to examine capital punishment in a totally different light.

Now the question is not whether capital punishment is a superior restraint, deterrence, or retributive measure for murder than is life without parole. The question is whether it is so vastly superior that it is worth the cost of innocent lives, condemned to death by the State. To my mind, the answer has to be "no." Life without parole in a secure prison is very nearly as effective a restraint as capital punishment. As for deterrence, even if we assumed a calculating defendant, how many would willingly kill another in exchange for life without parole, but would not willingly kill another if the penalty were death. Given the conditions of prison, at least in America, I have to believe that the number is exceedingly small.

Life without parole, however bleak a prospect, is at least correctable. Even one moved primarily by victim's rights has to grieve for the widow of a slain innocent, wrongly put to death by the State. And, of course, we may never know how many innocents actually have been executed because the system frequently stops looking for exculpatory evidence once the condemned has been executed. But, if the recent history of Illinois is any indication, the number of people wrongly executed may be more than we ever dreamed possible. ${ }^{31}$

${ }^{30}$ Though surely we can and should reduce the number

${ }^{31}$ After the Chicago Tribune exposed a number of failures by the Illinois justice system, Republican Governor (and long-time death penalty advocate) George Ryan declared a moratorium on executions in February of 2000. See Penny J. White, Errors And Ethics: Dilemmas In Death, 29 Hofstra L. REV. 1265, 1271 (2001). At the time of Governor Ryan's announcement, thirteen Illinois death-row inmates had been exonerated since 1977 while twelve had been executed. See Ken Armstrong \& Steve Mills, Ryan: 'Until I Can Be Sure': Illinois Is First State to Suspend Death Penalty, CHI. TRIB., FEB. 1, 2000, AT A1. 


\section{Do Not Condition Parole on Professions of Repentance}

A final suggested reform is for parole boards to abolish their requirement of contrition as a condition of parole. This is a fairly common practice, at least in the United States, and its upshot is that truly innocent people have to spend more time in prison for a crime than one who was actually guilty. It works this way: Jones and Smith were both convicted of robbing a convenience store in the year 2000. In 2006, both are eligible for parole. Jones, who was actually guilty, says: "I'm sorry," and is paroled. Smith, who was not guilty says: "I am sorry that the store was robbed and that the owner suffered great trauma, but I didn't do it." Typically a parole board will say: "I'm sorry Mr. Smith, but unless you accept responsibility for your crime, we cannot parole you." Thus Mr. Smith stays in prison. ${ }^{32}$

The system works well if we assume that everyone who was convicted was in fact guilty. Why shouldn't a guilty convict be required to show contrition before he is allowed to roam the streets again? But when we recognize that not all prisoners are in fact guilty, things change. Given that we know that we convict innocent people and that we can't completely fix the problem, it seems to me that we must not deny parole to an otherwise eligible prisoner whose only failing is a refusal to acknowledge responsibility for a crime that he says he didn't commit.

\section{Concluding Thoughts}

Twenty years ago, liberals/defense attorneys were thought to be concerned with winning acquittals. Never mind that the defendant was guilty. Find something wrong with the search warrant, point out that warnings weren't properly read, maybe counsel wasn't there on time. Just get the client off. Conservatives/prosecutors, on the other hand chastised their adversaries for making a game out of the process. ${ }^{33}$ In their view, truth was all that matter in criminal law, and

${ }^{32}$ One very high-profile example was the notorious "Central Park Five" case where a group of black and Latino youths were convicted of raping a jogger in central park. After their conviction a different person confessed and his DNA was found to match that discovered at the scene of the crime. The youths had all spent time in prison and had all been denied parole in part based on their lack of contrition. See N. Jeremi Duru, The Central Park Five, The Scottsboro Boys, and The Myth of the Bestial Black Man, 25 CARDOZo L. REv. 1315, 1319 (2004).

${ }^{33}$ See Chief Justice Burger's accusation that the Court is "playing a grisly game of 'hide and seek" by "exalting the sporting theory of criminal justice" in Brewer v. Williams, 430 U.S. 387, 417 (1997) (Burger, C.J., Dissenting). See also Justice Rehnquist's admonition in Florida v. Royer, 460 U.S. 491 (1983) that "The [majority] opinion. . . betrays a mind-set more useful to those who officiate at shuffleboard games, primarily concerned with which particular square the disc has landed on, than to those who are seeking to administer a system of justice whose twin purposes are the conviction of the guilty and the vindication of the innocent." Id. at 520 (Rehnquist, J. Dissenting). 
we shouldn't care who won or lost.

In some ways times have changed. Now liberals/defense attorneys worry about the number of innocent people who are being/have been convicted. The conservative/prosecutor line, on the other hand, has frequently been: "Hey game over, you lost. Let's keep the conviction." 34 Although there may be some truth to both sides, the concept of the criminal trial not being a game when an innocent person's life or freedom is on the line is something that we should all be able to embrace.

When an innocent person is convicted, we all lose (except of course, the actual guilty person). The real criminal isn't punished and is free to roam the streets and the State is forced to support an innocent person in prison who could possibly be leading a productive life for himself and his family on the outside. We can't completely prevent it, but we should abhor it, and do everything in our power to minimize it. The suggestions in this paper may not be all that we can do, but they are a step in the right direction.

${ }^{34}$ See e.g Herrara v. Collins, 506 US 390 (1993) discussed supra n. 22. 